\title{
PORADNICTWO - RÓŻNORODNE DROGI POSZUKIWANIA ROZWIĄZAŃ W SYTUACJACH TRUDNYCH
}

\section{COUNSELLING - VARIOUS WAYS OF FINDING SOLUTIONS IN DIFFICULT SITUATIONS}

\author{
Monika Wojtkowiak ${ }^{1(\mathrm{~B}, \mathrm{E}, \mathrm{F})}$
}

${ }^{1}$ Uniwersytet Jana Kochanowskiego w Kielcach

\begin{abstract}
Wojtkowiak, M. (2018). Poradnictwo - różnorodne drogi poszukiwania rozwiązań w sytuacjach trudnych. Rozprawy Społeczne, 12(3), $38-47$. https://doi.org/10.29316/rs.2018.25

Wkład autorów:

A. Zaplanowanie badań

B. Zebranie danych

C. Dane - analiza i statystyki

D. Interpretacja danych

E. Przygotowanie artykułu

F. Wyszukiwanie i analiza literatury

Streszczenie

Artykuł stanowi próbę wskazania nowych form działań pomocowych mieszczących się w obszarze poradnictwa. Szczególną uwagę poświęcono poradnictwu dialogowemu i jego zastosowaniu we współczesnych działaniach wspierających jednostkę w sytuacjach trudnych. Skoncentrowano się przy tym na potrzebach i ograniczeniach osób poszukujących pomocy, ale wskazano także nowe formy pracy, które mogą być odpowiedzią na rosnące zapotrzebowanie na pomoc w różnych zakresach (wzmacniania jednostki, rozwiązywania konfliktów, poszukiwania własnych zasobów).
\end{abstract}

G. Zebranie funduszy
Tabele: 0

Ryciny: 0

Literatura: 19

Otrzymano: grudzień 2017

Zaakceptowano: maj 2018
Słowa kluczowe: poradnictwo, pomoc, dialog, wsparcie

\section{Summary}

The article presents an attempt to indicate new forms of helping actions within advisory service. The emphasis is on the dialogic advisory service and its use in contemporary actions supporting the individual in challenging situations. The needs and restrictions of individuals looking for help are highlighted; however, new forms of work, which may be the answer to the rising need for help in various matters (strengthening the individual, solving conflicts, searching for new resources) have been indicated.

Keywords: advisory service, help, dialogue, support

\section{Wstęp}

Poradnictwo jest działaniem wpisanym w naturalne ludzkie funkcjonowanie społeczne i tak rozumiane można je traktować, jako wyraz społecznej adaptacji. Udzielanie wsparcia w nieformalnej i nieprofesjonalnej formie jest często oparte na ludzkim odruchu pomocy, który wpisany jest w nasze życie i ustala pewne interakcje na poziomie indywidualnym i społecznym. Od tak pojętego poradnictwa jeszcze daleko do pomocy profesjonalnej, której różnorakie formy będą opisane w poniższym opracowaniu. Wydaje się jednak zasadnym zauważenie, że jest to najprostszy sposób pomocy, wpisany w codzienność i związany z interakcyjnością ludzkiego funkcjonowania.

Obecnie możemy zauważyć zjawisko wzmożonego popytu na działania pomocowe. „Zapotrzebowanie $\mathrm{w}$ profesjonalną pomoc w świecie płynnej nowoczesności nie maleje" - pisze Violetta Drabik-Podgórna - „Przeciwnie, wraz z komplikacją codzienności (zawodowej, edukacyjnej, rodzinnej) wzrasta poczucie zagubienia i bezradności wobec coraz to nowych wyzwań" (Drabik-Podgórna, 2015, s.95.). Zmieniają się, zatem obszary życia, które wymagają pracy poradniczej, co implikuje konieczność poszukiwania coraz to nowych form pomocy i dróg jej udzielania.

Intencja niniejszego opracowania jest zwrócenie uwagi na nowe formy działań pomocowych i wspierających mieszących się w obszarze poradnictwa lub nawiązujących do niego. Zdecydowano się przy tym przyjąć następujący porządek prezentowanych treści: artykuł otwiera rozróżnienie definicyjne, które zwraca uwagę na wielość ujęcia problemu. Następnie, z racji przyjętej perspektywy zmienności poradnictwa, przeprowadzono krótką charakterystykę problemów, z którymi mogą zmagać się osoby zwracające się o pomoc. W kolejnym kroku dokonano opisu poradnictwa dialogowego, co wiąże się z zaakcentowaniem jego roli w opisanych później współczesnych formach pracy. Dobór prezentowanych form pomocy jest subiektywny, choć dyktowany koniecznością zauważenia różnorodnych sposobów działania i przenikania poradnictwa do metod pracy z pacjentami.

Adres korespondencyjny: Monika Wojtkowiak, Uniwersytet Jana Kochanowskiego w Kielcach, Wydział Pedagogiczny i Artystyczny, Zakład Profilaktyki Społecznej i Resocjalizacji, ul. Krakowska 11,25-029 Kielce, mwojtkowiak@ujk.edu.pl; ORCID: https://orcid.org/0000-0001-7611-8302 Copyright by: Państwowa Szkoła Wyższa im. Papieża Jana Pawła II w Białej Podlaskiej, Monika Wojtkowiak 


\section{Rozróżnienie definicyjne}

Różnorakie są definicje poradnictwa. Bywa ono wiązane $\mathrm{z}$ pomocą psychologiczną, ale stanowi również ważną gałąź działalności pedagogicznej i wychowawczej. Pomoc tego typu odnosi się do oddziaływań indywidualnych, grupowych (np. poradnictwo rodzinne), prowadzonych doraźnie lub będących procesem, posługujących się systemem zróżnicowanych metod i środków, odnoszącym do różnorakich dziedzin życia i problemów. Ta różnorodność zarówno w zakresie podmiotu, przedmiotu, jak i metod poradnictwa implikuje konieczność różnorakiego podejścia do opisu zjawiska i zauważenie, że poradnictwo jest procesem, którego opis zależy od przyjętej perspektywy.

Wielorakie koncepcje człowieka ujmują poradnictwo $\mathrm{w}$ różnych kategoriach, kładąc nacisk na rozliczne determinanty zachowania definiujące perspektywy pomocy. I tak:

1. Podejście psychodynamiczne zakłada, że „zachowanie człowieka jest sterowane przez czynniki wewnętrzne (siły motywacyjne), które nie są świadome i często zachodzi między nimi konflikt" (Skałbania, 2009, s.34.). Odwołanie się do możliwości i samodzielności pacjenta może opierać się $\mathrm{w}$ dużej mierze na zrozumieniu mechanizmów, które kierują jednostką i do ich zmiany. Poradnictwo psychodynamiczne jest zwykle działaniem długoterminowym, wymagającym czasu (Gąsior, 2016, s.17.).

2. Podejście behawiorystyczne kładzie nacisk na udział środowiska w determinowaniu zachowania ludzkiego. W tej perspektywie szczególnie istotnym jest to, czego środowisko dostarcza, traktując człowieka, jako reaktywnego, a więc podatnego na impulsy płynące $z$ otoczenia. Praca poradnicza opiera się $w$ tym rozumieniu głównie na poradnictwie dyrektywnym, dostarczającym klientowi „kary i nagrody”, a w rezultacie na kształtowaniu jego zachowań.

3. Koncepcje humanistyczne definiują poradnictwo, jako skoncentrowane na kliencie. Człowiek z jego niepowtarzalnością, dążeniem do samorealizacji, potrzebami, upodobaniami, emocjami staje, w centrum podejmowanych działań, które uwzględniają właśnie ów zestaw unikalnych cech.

4. Koncepcje poznawcze zajmują szczególne miejsce $w$ poradnictwie pedagogicznym. Zakładają one, bowiem, że „zachowania człowieka mogą być zmieniane dzięki systematycznym oddziaływaniom wychowawczym" (Skałbania, 2009, s.35.). Oddziaływania te powinny być oparte na zrozumieniu mechanizmów, według których działa człowiek, ale także indywidualnego systemu wartości, sposobu myślenia i patrzenia na świat.

Jak łatwo zauważyć, każda z wymienionych koncepcji proponuje nieco inne spojrzenie na jednost- kę, każda traktuje poradnictwo, jako działalność odnoszącą się do innej formy aktywności stron pracy pomocowej. Wielość perspektyw pociąga za sobą wielość definicji poradnictwa, jako procesu.

Klasyczna już definicja Olgi Czerniawskiej, określa poradnictwo, jako „działanie polegające na niesieniu pomocy za pośrednictwem porady, przy czym przez działanie rozumie się układ relacji między dwiema lub większą liczbą osób" (Czerniawska, 1977, s.7). W niniejszym procesie ważne są zarówno podmiotowe cechy obu stron relacji, jak dobór metod, środków, form pomocy, które przyczynić się mogą do sukcesu działalności poradniczej. Poradnictwo według Stevena Murgatroyda „stanowi złożony, subtelny i niekiedy pełen napięcia proces, w którym co najmniej dwie osoby nawiązują ze sobą kontakt i próbują doprowadzić do określonej zmiany" (Murgatroyd, 2000, s.17). Przy czym, jak zauważa dalej Autor, zmiana ta może być całkiem prosta-pozwala zrozumieć zaistniałą sytuację, ale może również prowadzić do poważnych zmian w sposobie życia danej osoby.

Takie ujęcie poradnictwa koresponduje z definicją Anny Jones, którą określiła je, jako „działanie ułatwiające poszczególnym osobom pogodzenie się z własnym życiem - takim, jakie ono jest - a w ostatecznym rachunku pomagające osiągnąć większą dojrzałość poprzez nauczenie się brania odpowiedzialności i podejmowania decyzji za samego siebie" (Murgatroyd, 2000, s.17). W takiej perspektywie należy zwrócić uwagę na dwie kluczowe kwestie: po pierwsze powyższa definicja podkreśla efektywność poradnictwa nie tylko w kategorii zażegnania kryzysu czy wzmocnienia jednostki, ale: wyposażenia jej w umiejętności potrzebne do refleksyjnej samodzielności. Oznacza to, że jednostka nie tylko będzie potrafiła poradzić sobie z problemem, który ma miejsce tu i teraz, ale będzie świadoma konieczności podejmowania samodzielnych działań w celu zapobieżenia sytuacjom trudnym na przyszłość lub radzenia sobie z nimi, gdy już nastąpią. Drugim istotnym elementem powyższego ujęcia jest określenie adresatów poradnictwa. Pamiętać należy, że poradnictwo nie odnosi się wyłącznie do działań adresowanych do jednostki, może być również działaniem podejmowanym wobec większych grup a nawet społeczności. Ale, jak wydaje się wskazywać powyższa definicja, poradnictwo jest zespołem czynności, które w swej istocie sprowadzają się do kontaktu dwojga ludzi, uwzględniają ich indywidualności i charakter, ujmują uczestników poradnictwa w szerokim spectrum ich cech i preferencji. Tym bardziej docenić należy wartość takiego ujęcia poradnictwa, które to ujęcie wydaje się korespondować z proweniencją procesu-jest to przecież działanie wywodzące się z naturalnych interakcji międzyludzkich, w których porada czy

Steven Murgatroyd zaznacza przy tym, że zmiany osiagane w efekcie poradnictwa mogą być niewielkie,(kiedy na przykład uzmysłowimy sobie coś), lub też dotyczą znacznej zmiany myślenia i odczuwania. Celem pomocy jest wspieranie danej osoby w przejmowaniu większej kontroli nad swym życiem" (Murgatroyd, 2000, s.16.). 
pomoc mają stałe miejsce. Oczywiście poradnictwo wymaga określonych umiejętności, profesjonalnego przygotowania i formalnych kompetencji, ale w dużej mierze sukces porady zależy od cech osobowych uczestników relacji.

\section{Trudności po stronie osoby poszukującej pomocy}

W centrum każdej porady stoi klient, pacjent, osoba potrzebujacca pomocy. Jak słusznie zauważa Ewa Bilska poszukiwanie porady jest procesem decyzyjnym, poprzedzonym subiektywnym odczuwaniem dyskomfortu i niepewności. Autorka stworzyła swoistą listę etapów, przez które przechodzi jednostka poszukująca pomocy w sytuacji przemocy. Rejestr ten wydaje się jednak dość wyczerpującym i wartym przytoczenia również w przyjętej w niniejszym artykule perspektywie. I tak:

- w pierwszym etapie jednostka, uznaje, że w jej otoczeniu mają miejsce zdarzenia, zachowania innych ludzi, lub ma miejsce sytuacja, która różni się od dotychczasowej, ale „uznaje, że nie dzieje się nic, czego powinna się bać”,

- etap drugi - „czy to jest problem?” to moment porównywania swojej sytuacji $\mathrm{z}$ sytuacją innych ludzi, ale jednostka niekoniecznie uznaje, że problem rzeczywiście ma miejsce, bywa, że w tym momencie określa siebie, jako osobę mniej zaradną niż wszyscy, niepotrafiącą sobie radzić tak, jak inni,

- w trzecim etapie jednostka prawdopodobnie potrafi już zidentyfikować sytuację, ale stara się nie określać problemu, jako „większego niż inne",

- kolejny, czwarty etap, to próba wyjaśnienia lub usprawiedliwienia swojej sytuacji fatum, czynnikami zewnętrznymi etc. Taki zabieg służyć ma usprawiedliwieniu własnej bierności i niepodejmowania prób rozwiązania problemu,

- piąty etap to próby „radzenia sobie”, „bycia dzielnym", podejmowania pierwszych aktywnych wysiłków zmierzających do radzenia sobie z sytuacją,

- w szóstym etapie dochodzi do swoistej kalkulacji podejmowania pomocy u innych, na ogół związanej z poczuciem wstydu, upokorzenia. Zwykle w tym momencie decyzja o skorzystaniu z pomocy jest odkładana na później,

- siódmy etap jest kontynuacją wcześniejszego, jednostka zadaje sobie pytania o to, „czy jest ktoś, kto mógłby mi pomóc?”, na tym etapie zwykle poszukuje pomocy u krewnych, bliskich, znajomych, dopiero potem u specjalistów,

- ostateczna decyzja o zwróceniu się o pomoc zapada na ósmym etapie. Jest to moment, w którym jednostka podejmuje działanie, zaczyna aktywnie poszukiwać pomocy (Bilska, 2012, s.183-184.).

Powyższy schemat, mimo, że zaczerpnięty z sy- tuacji poszukiwania pomocy określonego typu (przemoc w rodzinie), zawiera wiele elementów, które wydają się pojawiać w różnorodnych realiach kryzysów, przed którymi stają jednostki. Wydaje się, zatem trafnym zabiegiem uwzględnienie niepewności i poczucia zagubienia, które towarzyszy jednostce zanim ta zdecyduje się na skorzystanie z pomocy. Pamiętać należy również, że nierzadko ta decyzja nie jest jeszcze gwarantem rzeczywistego skorzystania z różnorakich form wsparcia. Poradnictwo, bowiem w realiach polskich kojarzone jest z przyznaniem się do bezsilności i często piętnowane w środowisku, obarczone wstydem i traktowane, jako synonim nie radzenia sobie.

W literaturze przedmiotu można znaleźć wielu prób skatalogowania barier odnośnie korzystania z poradnictwa. Najczęściej wśród nich wymienia się:

- wspomniane już: niewiarę w możliwość zmiany i w skuteczność pomocy,

- lęk przed porażką, często ujmowany w krótkie komunikaty typu: „moja sytuacja jest beznadziejna”, „to nic nie da”,

- lęk przed otwarciem się przed doradcą, nieumiejętność zaufania,

- brak wiary w siebie i możliwość zmiany,

- silnie zakorzenione myślenie nawykowe o swoich niepowodzeniach i lęk przed wejrzeniem w siebie,

- brak chęci do zmiany, konformizm polegający na poczuciu stabilności nawet w sytuacji trudnej,

- oczekiwanie, że zmiany nastąpią w otoczeniu, niechęć lub niedocenianie „małych kroków”, brak cierpliwości w pracy,

- oczekiwanie szybkich zmian, „gotowych recept", natychmiastowej poprawy sytuacji,

- brak chęci inwestowania czasu, autentycznego wysiłku, niesumienność pracy, nie traktowanie pomocy w sposób konsekwentny, niewywiązywanie się z podjętych podczas spotkań poradniczych zobowiązań,

- nierealne oczekiwania wobec doradcy-np. natychmiastowej zmiany, tego, że doradca nauczy klienta manipulacji osobami z jego środowiska,

- skupianie się na szukaniu usprawiedliwień, wzbudzaniu współczucia, koncentracja na przeszłości (Ćwikła, 2012, Murgatroyd, 2000, Kuczyńska, 1985).

Osobną kategorię przeszkód, które mogą pojawić się w poszukiwaniu (a potem korzystaniu z) pomocy są problemy związane ze środowiskiem. Sytuacja różnicuje się już biorąc pod uwagę niewielkie społeczności i wielkomiejskie warunki sprzyjające anonimowości. Silnie zakorzenione przekonanie o tym, że istnieje duża kontrola społeczna, „wszyscy wiedzą wszystko”, połączone ze wspomnianym powyżej stereotypem „radzenia sobie samemu” nie sprzyja podejmowaniu jakichkolwiek działań w kierunku poszukiwania i korzystania z pomocy 
profesjonalnej. Ponadto bardzo często klient obawia się reakcji najbliższego środowiska, lub wręcz oczekuje, że porada stanie się „złotym środkiem” i natychmiast zmieni osoby w jego otoczeniu. Laura Ćwikła wspomina również o problemach wynikających z roszczeniowych postaw osób z otoczenia jednostki, które często wiążą się $\mathrm{z}$ nastawieniem klienta określanym potocznie „płacę i wymagam”. Taka sytuacja może łączyć się ze zjawiskiem komercjalizacji poradnictwa i traktowania doradcy, jako „sprzedawcy usług”, co nie sprzyja budowaniu autentycznej i szczerej relacji (Ćwikła, 2012, s.62). W kategoriach bariery możemy również traktować sytuację, w której osoba kierowana jest po poradę przez osoby trzecie (pracodawcę, rodzinę, kuratora) lub gdy owo „kierowanie” ma charakter wywieranej na nią presji.

Te i inne czynniki tworzą wielość argumentów, „przeciw”, które nierzadko przeważają o tym, że osoby nie decydują się na korzystanie z fachowego wsparcia. Implikuje to refleksje o potrzebie swego rodzaju promocji poradnictwa, jako formy pomocy i wsparcia, a także inicjuje pytania o to czy, (a jeśli to: jak?), należy dostosować poradnictwo do potrzeb współczesnych odbiorców.

\section{Dialog jako narzędzie poradnictwa}

Poradnictwo możemy bardzo ogólnie traktować, jako specyficzne spotkanie, w którym spotykają się osoby wyposażone w różnorakie cechy i doświadczenia. Jest ono oczywiście działaniem profesjonalnym, a więc zamkniętym ramami celów, narzędzi i zasad, jednak jego personalny wymiar realizuje się w przebiegu procesu. Nie sposób nie docenić w poradnictwie właśnie niepowtarzalności relacji, która ma miejsce między doradcą a klientem i roli, jaką w niniejszej relacji pełni dialog.

Dialog według Mieczysława Łobockiego :

- pozwala na obustronną wymianę myśli i poglądów,

- umożliwia dzielenie się doświadczeniem i osobistymi przeżyciami,

- ułatwia wzajemne poznanie się, również poznanie motywów, potrzeb, zainteresowań osób,

- pozwala na ocenę własnego postępowania i zrozumienie postępowania innych,

- daje możliwość rozładowania negatywnych napięć,

- zapewnia poczucie ważności i wsparcia a także

- uświadamia odpowiedzialność za swoje postępowanie i działania (Łobocki, 2007).

Wartość dialogu w poradnictwie wydaje się, zatem nieprzeceniona. Strony uczestniczące $\mathrm{w}$ nim, mają poczucie swego rodzaju współodpowiedzialności w budowaniu porozumienia, co może znaleźć przełożenie na poprawę sytuacji osoby szukającej pomocy. Dialog ma przy tym niewątpliwy walor w dawaniu odczucia partnerskiego traktowania, szacunku i bliskości. Odpowiednio prowadzony daje możliwość zawiązania relacji poradniczej, która wspiera otwartość, zaufanie i szacunek stron w budowaniu porozumienia i osiągnięcia wymiernych zmian.

Wydaje się, że dialogowe poradnictwo ma ogromny potencjał dzięki kilku jego cechom charakterystycznym. Przede wszystkim poradnictwo dialogowe jest swego rodzaju formą odejścia od autorytatywnego traktowania klienta przez doradcę. Koncentruje ono uwagę na osobie poszukującej pomocy i przenosi odpowiedzialność za budowanie relacji również na nią. $W$ ten sposób zakłada się większą aktywność klienta i akcentuje konieczność podjęcia odpowiedzialności za sukces porady. Ponadto poradnictwo dialogowe zakłada, bardziej, niż poradnictwo dyrektywne i liberalne, partnerskie traktowanie się stron. ${ }^{2}$ Dostrzegając potrzeby partnera, czasem również odkrywając jego ukryte motywy i interesy strony mają możliwość nie tylko poszerzenia wiedzy o drugiej stronie, ale także lepszej i pełniejszej kooperacji.

\section{Nowe koncepcje pomocy}

Dynamiczne przeobrażenia ekonomiczne i społeczne implikują również zmiany w stylu życia i funkcjonowania współczesnych. Wydaje się, że zmieniają się również potrzeby i oczekiwania w zakresie udzielanej pomocy. Pociąga to za sobą konieczność wprowadzenia modyfikacji w proponowanych formach pracy z osobami potrzebującymi (i poszukującymi) wsparcia. Ich wyrazem może być postępująca popularność coachingu, jako formy pomocy i wspierania.

Coaching jest na ogół łączony $\mathrm{z}$ doradztwem, ale także terapią i nauczaniem. Stanowi on formę pomocy niedyrektywnej, skoncentrowanej na przyszłości i założonych celach. Wykorzystanie coachingu opiera się na poszukiwaniu rozwiązań prowadzących do likwidacji luki między stanem obecnym, (w którym odczuwamy jakiś deficyt, kryzys, etc.) a stanem pożądanym (Kozielska, Skowrońska -Pućka, 2015, s.44).

Jego głównym założeniem jest osiągniecie jasno sprecyzowanego, optymalnego celu poprzez wykorzystanie zasobów jednostki. „Coaching jest narzędziem wspomagania rozwojowych zmian, ale to także pewien styl bycia, styl komunikacji, styl radzenia sobie z sytuacjami problemowymi" (Kozielska, Skowrońska-Pućka, 2015, s.44). Czynnikiem, który wpływać może na popularność coachingu jako formy pomocy jest akcentowanie samodzielności klienta i niemal całkowite odejście od dyrektywności w działaniu pomocowym.

\footnotetext{
${ }^{2}$ W tym miejscu warto zauważyć, że o ile poradnictwo dyrektywne opiera się na dość instrumentalnym traktowaniu porady i przejmowaniu przez doradce roli eksperta, zaś poradnict wo liberalne koncentruje się na zapewnieniu klientowi bezpiecznej atmosfery dla podjęcia samodzielnych działań, to poradnictwo dialogowe koncentruje się właśnie wokół dialogu, rozmowy, wymiany informacji służącej partnerskiej relacji: doradca-klient (Skałbania, 2009).
} 
Zasady coachingu określają również możliwości wyboru formy działania w interakcji między stronami:

1. Zakłada się, że klient, posiada pewien potencjał zasobów, często różnorodnych, które mogą pomóc mu w wyjściu z sytuacji trudnej.

2. Po drugie zauważa się, ze klienci znają swoje mocne strony, mogą jednak nie mieć świadomości możliwości ich wykorzystania - w czym może pomóc im doradca (np. poprzez zadawanie pytań, prowokowanie do narracji).

3. Trójtemporalność perspektywy czasowej w coachingu zakłada, że każdy z nas kreowany jest przez przeszłość, teraźniejszość i przyszłość, jednak szczególna rola w poprawie sytuacji przypada przyszłości.

4. Klient wybiera temat rozmowy, co często dyktowane jest aktualnymi wydarzeniami z jego życia.

5. Coaching jest formą pomocy, w której obie strony (klient i coach) są sobie równe, przy czym różne są ich zadania i zakres odpowiedzialności. Klient odpowiada za cel, do którego dąży, coach czuwa nad porządkiem i metodyką procesu.

6. Dochodzenie do zmiany powinno przebiegać bez oceniania, a jego efektywność w dużej mierze opiera się na wzajemnym szacunku i współpracy (Kozielska, Skowrońska-Pućka, 2015, s.44).

Można, zatem powiedzieć, że w tej formie pomocy coach jest jedynie przewodnikiem, doradcą, jednak zarówno cel jak i skuteczność powodzenia procesu w największym stopniu zależy od klienta. Na pewno ogromną zaletą tej formy pracy jest położenie szczególnego nacisku na samoodpowiedzialność i wspieranie samodzielności w uświadamianiu sobie własnych cech i rozwoju zasobów. Podkreślić należy jednak, że jest to forma pomocy wymagająca zaangażowania po stronie klienta, gdyż zbudowanie partnerskiej relacji w dużej mierze spoczywa również na jego barkach. „Proces coachingowy ma charakter relacyjny a jego podstawą jest dialog, partnerstwo i zaufanie" (Kozielska, Skowrońska -Pućka, 2015, s.48).

Podobna formą działalności pomocowej jest Life-Desing Counseling lub Like structure counseling. Podstawą tej formy działania jest uznanie roli samowiedzy i tożsamości, które kształtują się w toku doświadczeń życiowych. Podstawową metodą pracy w tego rodzaju pomocy jest wsłuchiwanie się w historię życia: klient opowiada o własnych doświadczeniach, przebytych wydarzeniach, problemach, które spotkał (M.L.Savickas, Life-Desing Counseling Manual, 2015, s. 9. Dokument w wersji elektronicznej dostępny pod adresem: http://www.vocopher.com/LifeDesign/ LifeDesign.pdf dostęp z dnia 30 września 2017). W historii życia (life-story) ujawniaja się elementy ekosystemu, w którym funkcjonuje jednostka, drogi jej adaptacji, jak również sposoby radzenia sobie na różnych etapach życia. Przed doradcą staje, zatem nowe zadanie. Już nie tylko udziela on rad, ale stara się przedstawić, jako realne i osiągalne nowe perspektywy rozwoju, zachęca klienta do odkrywania siebie, swojego życia, tworzenia wizji dobrej przyszłości. Współczesny doradca towarzyszy, wspiera, inspiruje.

Mimo, że Life-Desing Counseling wiąże się nierozerwalnie konstruktywizmem, jego rodowodu dopatrywać można się także w poszukiwaniu potencjału jednostki a nawet w budowaniu mechanizmów prężności. Ostatecznie zmierza, bowiem do poprawy zdolności adaptacyjnych i samodzielnego konstruowania swojego życia, projektowania go w oparciu o własne doświadczenia, możliwości i zdolności.

\section{Poradnictwo przez Internet - czy to już „porad- nictwo instant"?}

Choć Internet wszedł w użycie już ponad dwadzieścia lat temu (http://www.siteimpulse.com/ blog/archiwum-historia-i-komercjalizacja-sieci/ dostęp z dnia 30 września 2017) można powiedzieć, że od stosunkowo niedawna stał się przestrzenią funkcjonowania ludzi, w której nie tylko szukają rozrywki, ale także przenoszą doń coraz więcej obszarów swojego życia. Współcześni już nie tylko komunikują się przez Internet, ale również poszukują tam znajomości, prowadzą w e-przestrzeni życie towarzyskie, czerpią $\mathrm{z}$ niej informacje, korzystają z niej w pracy,, a nawet szukają w niej pomocy. Ten ostatni zakres stał się polem do wykorzystania dla prowadzenia działalności poradniczej. W tym miejscu podkreślić trzeba, że mimo powyższego podtytułu- nawiązującego wprost do określenia „pokolenie instant”, w Internecie znajduje swoje miejsce funkcjonowania coraz większa społeczność ludzi reprezentujących pokolenia starsze. To zjawisko wydaje się znakiem czasu, ale może również koniecznością-nie sposób, bowiem funkcjonować w oderwaniu e- przestrzeni.

Jako główne atrybuty Internetu wymienia się na ogół: szybkość przesyłu informacji, (która pozwala na niemal nieprzerwany kontakt między użytkownikami również w czasie rzeczywistym), elastyczność czasowa i przestrzenną (jest medium, które jako jedyne daje poczucie znoszenia barier odległości), a także poczucie bezpieczeństwa związane z anonimowością, (co skutkuje większą otwartością użytkowników). Ta ostatnia cecha ma swoje implikacje w zakresie, jakości komunikacji, a nawet funkcjonowania w przestrzeni wirtualnej. O cechach e-przestrzeni będzie jeszcze mowa w niniejszym opracowaniu. W tym miejscu należy skoncentrować się na specyficznym zakresie ludzkiego działania w Internecie a mianowicie: poradnictwie prowadzonym za pomocą sieci.

"Określenie pokolenie instant" odnosi się najcześciej do najmłodszych użytkowników Internetu, z racji preferowania przez nich skrótowego zwartego, szybkiego sposobu komunikacji i charakteryzujących ich zachowań zmierzających do osiągniecia efektu „natychmiast, szybko, bez wysiłku". 
Pojawienie się e-poradnictwa było naturalnym zjawiskiem związanym ze wspomnianym już przenoszeniem kolejnych obszarów ludzkiej działalności do przestrzeni wirtualnej. „Pomoc on-line jest fachową formą usług psychologicznych świadczonych zdalnie, głownie za pomocą mediów takich jak Internet czy wideotelefon" (Pomoc psychologiczna on-line? Wywiad z profesorem Bassamem Aouilem. Dokument dostępny pod adresem http:// www.psychologia-spoleczna.pl/wywiady/284-pomoc-psychologiczna-on-line-wywiad-z-profesorem-bassamem-aouilem.html, aktualizacja $\mathrm{z}$ dnia 4.10.2017). Tego rodzaju działalność obejmować może działania interwencyjne, poradnictwo pedagogiczne i psychologiczne, jak i długofalową pomoc. Barbara Skałbania charakteryzując poradnictwo prowadzone za pomocą e-mediów słusznie zauważa, że „można (je) analizować w ujęciu szerokim, co dotyczy programów mających jasno określone cele, inne niż poradnicze, oraz w ujęciu węższym, co dotyczy programów, prasy czy sytuacji związanych z doradztwem, udzielaniem instruktażu, wsparcia, dostarczaniu wskazówek, porad z rożnych dziedzin życia" (Skałbania, 2000, s.61). Przyjmując tą perspektywę można zaliczyć poradnictwo internetowe do poradnictwa zapośredniczonego, czyli pozbawionego bezpośredniego kontaktu między doradcą a klientem (Smól, 2009, s.60).

Autorzy, min. Barbara Skałbania, Tonito Cantelmi, Giardina Grifo (Skałbania, 2009, s.91, Cantelmi, Grifo, 2003, s.46) podają różnorakie cechy wpływające na możliwość udzielania poradnictwa przez Internet,

- interaktywność, która może istotnie wpływać na nawiązywanie dużej ilości kontaktów przy niewielkim nakładzie czasu i wysiłku,

- anonimowość, zwiększającą chęć otwarcia się, łagodzącą poczucie ryzyka narażenia się na wstyd, (niestety również) minimalizującą znaczenie norm społecznych,

- wyobraźnię, która powoduje większą otwartość i śmiałość w nawiązywaniu kontaktów społecznych.

Powyższe elementy mogą wpływać na większe poczucie bezpieczeństwa użytkowników i co za tym idzie większa pewność siebie. Podkreślić trzeba, że dla wielu użytkowników jest to środowisko „oswojone”, bliskie, codzienne, pozbawione elementu czegoś nowego, niepewnego. Poszukując porady czy pomocy w wirtualnej przestrzeni potencjalny klient nie przeżywa stresu związanego z wizytą w gabinecie doradcy, nie obawia się tego, że będzie narażony na bezpośredni kontakt z obcą osobą, ma pełną świadomość, że może „ukryć się” za monitorem i ewentualnie przerwać kontakt w wybranym przez siebie momencie. Szeroka oferta poradnicza, jaką znajdziemy w Internecie obejmuje zarówno porady indywidualne jak i te, które kierowane są do grup odbiorców.

„Za pośrednictwem sieci możliwe jest, na podstawie własnych doświadczeń, udzielanie pomocy w zakresie zaburzeń zachowania i trudności przystosowawczych np.:

a) radzenia sobie w trudnej lub kryzysowej sytuacji osobistej, rodzinno-partnerskiej, zawodowej i społeczno-życiowej;

b) radzenia sobie z chorobą własną lub osób bliskich oraz z jej konsekwencjami;

c) rozwiązywania problemów związanych z uzależnieniem od alkoholu lub narkotyków;

d) rozwiązywania problemów partnerskich i seksualnych;

e) rozwiązywania problemów osobistych na tle systemu wartości;

f) rozwiązywania problemów wychowawczych i szkolnych;

g) zapobiegania zagrożeniom i rozwiązywania aktualnych problemów w taki sposób, by służyły rozwijaniu samodzielności, odpowiedzialności i umiejętności podejmowania decyzji;

h) zapobiegania zagrożeniom i pomoc w radzeniu sobie z zachowaniami lękowymi, agresją, samoagresją itp.;

i) kształtowania adekwatnej samooceny, uczenia się akceptacji siebie i bycia sobą;

j) wyboru i realizacji celów życiowych;

k) tożsamości płciowej czy osobistej" (Plichta, Pyżalski, 2013).

Wachlarz ofert pomocy jest bardzo obszerny, co pozwala na znalezienie jej przez bardzo różnych klientów. Na jednej ze stron internetowych oferujących usługi poradnicze -,poradnictwo psychologiczne.pl” znajdujemy rozróżnienie grup odbiorców tego typu porad.

Są to:

- osoby, które ze względu na silne, negatywne emocje, (takie jak lęk, wstyd, zażenowanie) nie mają ochoty lub nawet obawiają się bezpośredniego kontaktu z doradcą,

- osoby, którym warunki organizacji życia utrudniają bądź ograniczają możliwość przyjścia do gabinetu. (Powodów takiej sytuacji może być kilka, np. miejsce zamieszkania, rodzice pozostający z małymi dziećmi, lub pracujący w godzinach uniemożliwiających dojazd do specjalisty),

- osoby z niepełnosprawnością fizyczną utrudniającą poruszanie się,

- osoby chcące przy korzystaniu z pomocy wyjść poza własne środowisko, lub te, w których środowisku etykietuje się korzystanie z pomocy,

- osoby młode, dla których środowisko Internetu jest środowiskiem znanym, pozbawionym rysu „czegoś nieprofesjonalnego” (poradnictwo psychologiczne.pl, dostęp $\mathrm{z}$ dnia 10.09.2017).

\section{Cechy szczególne poradnictwa internetowego}

Profesor Bassan Aouil charakteryzując poradnictwo prowadzone online, zauważa, że jest to 
poradnictwo silnie akcentujące rolę pacjenta. To pacjent decyduje czy taki rodzaj pomocy mu odpowiada, to on redaguje przebieg procesu, wreszcie to pacjent jest bezpośrednio odpowiedzialny za poziom zaangażowania i ostatecznie często sukces poradnictwa. Jednocześnie Profesor zauważa specyficzne dla tego rodzaju poradnictwa wady i zalety. Jak się okazuje, podstawowa z wad odnosi się specyfiki środowiska Internetu, który często postrzegany jest, jako środowisko rozrywki i spędzania czasu wolnego. Również „wielu psychologów bardzo sztywno trzyma się pewnych stałych zasad pomocy bezpośredniej i uważa, że bez nich pomoc nie jest profesjonalna" (Palmisano, 2017).

Istotnym zagadnieniem jest koniczność podnoszenia kwalifikacji osób udzielających pomocy. Przede wszystkim chodzi o wyposażenie ich w kompetencje komunikacyjne: Internet wydaje się posługiwać komunikacją określaną, jako skrótowa, lakoniczna, szybka. Tymczasem doradca działający w Internecie powinien potrafić nawiązywać i podtrzymywać kontakt online, konstruować poradę w sposób zrozumiały i niedwuznaczny, konieczna jest znajomość form udzielania pomocy i przestrzegania etyki zawodowej.

Warto podkreślić, że kontakt pomocowy realizowany online pozbawiony jest możliwości obserwacji reakcji niewerbalnych, co implikuje konieczność koncentracji na komunikatach również w zakresie odkrywania interesów ukrytych czy demaskowania działań zawierających ukrytą manipulację. Wśród wad tego rodzaju poradnictwa wymienić można również możliwość przekroczenia zasad etycznych, trzeba, bowiem pamiętać o możliwościach zapisu prowadzonych rozmów, a także ewentualnego nieetycznego ich wykorzystania przez osoby niepowołane.

Rozwój środowiska cyfrowego wydaje się determinować rosnące potrzeby na działania pomocowe mające miejsce $w$ e-przestrzeni. Wśród zalet tej gałęzi pomocy Profesor Bassan Aouil wymienia przede wszystkim ogromna dostępność poradnictwa, które nareszcie przekroczyło narzucone odległością geograficzną i barierami ekonomicznymi granice. Dzięki Internetowi pacjent może znaleźć pomoc i skorzystać z niej w każdej chwili. E-poradnictwo znosi również bariery wynikające $\mathrm{z}$ koniecznością wizyty w gabinecie czy obawa przed kontaktem „twarza w twarz” z doradcą. Nawet posługiwanie się swobodnym i bezpośrednim językiem w tego typu kontakcie internetowym może być traktowane, jako wymierna zaleta e-poradnictwa. Niewątpliwym walorem tego rodzaju działań jest możliwość ustalenia zapisu pewnych treści przez strony procesu poradniczego. Daje to szansę na powtórną analizę treści, powrót do nich, pogłębioną refleksję i zastanowienie się (Palmisano, 2017).

Osobną kategorię wątpliwości związanych z poradnictwem online stanowi szereg zjawisk związanych z autokreacją i e-identyfikcją użytkowników.
Determinuje to konieczną refleksję na temat etycznego wymiaru działań pomocowych wobec możliwości fałszowania danych.

\section{Wybrane formy i modele poradnictwa interne- towego}

Przeobrażenia związane z poszerzaniem się dostẹpu do Internetu wiążą się $\mathrm{z}$ dynamicznym rozwojem technologicznym. Internet jest medium, które rozwija się szybciej niż wszelkie, go poprzedzające, dlatego, w dużej mierze prognozowanie tego, jak będą wyglądały zmiany w jego uży waniu jest kwestią futuryzmu i trudno jednoznacznie stwierdzić, jaki kształt będzie miało za kilka lat również poradnictwo internetowe.

Najogólniej można podzielić poradnictwo udzielane tą drogą na kilka typów:

- porada w czasie rzeczywistym (np. rozmowa online) przy użyciu komunikatorów, a także środków audio i audio-video,

- porada udzielana za pomocą e-maila, w której czas porady nie jest jasno określony i zamknięty w jednej sesji poradniczej, oraz

- porada poprzez fora internetowe, która ma charakter bardziej ogólny (i nie zakłada wyłącznie odbiorcy indywidualnego).

Należy pamiętać, że poradnictwo internetowe winno zachować profesjonalny charakter, który wyraża się nie tylko w odpowiednim przygotowaniu doradców, ale także w uporządkowaniu i pewnej planowości podejmowanych działań. Zakłada się, że pierwsze spotkanie on-line ma obejmować właśnie uporządkowanie kwestii organizacyjnych i przedstawienie swego rodzaju planu działań. Podczas pierwszej sesji podejmuje się, zatem następujace kroki:

- wstępną diagnozę,

- przedstawienie możliwości planowanych w przyszłości działań,

- prezentacja ram organizacyjnych (czas trwania sesji, ilość sesji, kwestie sposobów prowadzenia poradnictwa),

- wyjaśnienie kwestii etycznych i kwestii tajemnicy zawodowej,

- plan działań na wypadek nieprzewidzianych trudności technicznych (poradnictwo psychologiczne.pl, dostęp z dnia 30 września 2017).

Bardzo istotnym zagadnieniem w organizacji poradnictwa tego typu, jest poszanowanie zasad profesjonalizmu i transparentności poradni internetowych. Pacjenci powinni mieć możliwość zapoznania się $\mathrm{z}$ regulaminem poradni a także $\mathrm{z}$ uprawnieniami i przygotowaniem zawodowym specjalistów w niej zatrudnionych.

Poradnictwo prowadzone za pośrednictwem Internetu doczekało się własnej metodyki postępowania i nadal wydaje się ekspresyjnie rozwijać różne formy pracy. Pośród wielorakich form pomocy najpopularniejsze jest poradnictwo krótkoterminowe, ale nie jest ono jedyną formą działań profe- 
sjonalnych podejmowanych w ramach działalności poradniczej.

Dariusz Skowroński i Katarzyna Waszyńska wymieniają dwa modele e-poradnictwa:

Model czterech maili (4-Session model), który zakłada oparcie się na podejściu narracyjnym i koncentrację na uczuciach i emocjach, jakie powoduje u klienta problem. Działanie poradnicze zamyka się w tytułowych czterech e-mailach, które są niejako krokami, podejmowanymi w postępowaniu poradniczym i zmierzają ostatecznie do samodzielności w stawianiu czoła przyszłym problemom przez pacjenta.

1. Pierwszy email służyć ma zapewnieniu poczucia bezpieczeństwa, zdefiniowaniu (lub przedefiniowaniu) problemu i nawiązaniu odpowiedniego kontaktu miedzy doradcą a klientem. Ten pierwszy kontakt służy także podkreśleniu roli i zasobów pacjenta.

2. Drugi email koncentruje się na opisie mechanizmów, które moga przyczyniać się do podtrzymania sytuacji trudnej (mogą to być przyzwyczajenia, mity, stereotypy, które wpływają na ludzkie działanie). Jest to etap, na którym w dalszym ciągu podkreśla się zasoby klienta, ale także pozostawia mu możliwość rozwiązywania pewnych zadań.

3. Trzeci email koncentruje się na zmianach w percepcji klienta, które prowadzić mogą do poprawy jego sytuacji w przyszłości. Doradca wspiera, motywuje i dostrzega pozytywne zmiany. Posługuje się przy tym treściami, które pochodzą od pacjenta-przeformułowuje je, parafrazuje, podkreślając, że pacjent sam dostrzega możliwości zmiany, sam je nazywa i definiuje.

4. Czwarty email jest swoistym podsumowaniem, które zamyka proces. Doradca wskazuje samodzielność klienta i motywuje go do dalszej pracy (Skowroński, Waszyńska, 2015).

Ten model poradnictwa niejako „krok po kroku” porządkuje podejmowane działania. Jego zaletą jest skoncentrowanie tychże działań, jasne określenie ich celowości i dookreślenie zasad rządzących procesem. Być może, dlatego powyższy model jest dość często stosowany $\mathrm{w}$ poradnictwie internetowym i doczekał się rozlicznych adaptacji i modyfikacji.

Podobna formę ma E-PLISSIT model autorstwa J.S.Annona - najczęściej jest wykorzystywany w poradnictwie zdrowia i poradnictwie związanym $\mathrm{z}$ interwencją seksuologiczną. Obejmuje on następujące etapy:

- przygotowanie, tworzenie przestrzeni poradniczej, w której klient będzie mógł otworzyć się i szczerze porozmawiać,

- dostarczanie informacji pacjentowi,

- przedstawienie możliwych rozwiązań w oparciu o swego rodzaju diagnozę, zachęcanie do samodzielnego rozwiązania problemu,

- udzielanie wszechstronnego wsparcia, porad, ewentualne wskazanie możliwości otrzyma- nia innych form pomocy (Palmisano, 2017).

Model jest dość prosty, pozwala na dowolne modyfikacje w obrębie każdego z etapów, jest elastyczny i daje możliwość dostosowania działań zarówno do indywidualnej sytuacji poradniczej jak i niepowtarzalnych cech każdego z klientów.

Poradnictwo prowadzone przez Internet jest, jak już wspomniano działaniem specyficznym, najczęściej wykorzystywanym do interwencji i relacji pomocowej, krótkotrwałej.

\section{Podsumowanie}

Obecne zjawiska społeczne i kulturowe nadają współczesności nie tylko specyficzne ramy, w których funkcjonujemy, ale także szybkie tempo, które ma swoje konsekwencje również w wielości sytuacji trudnych, wobec których stajemy. Mnogość problemów, które się z tym wiążą, wymyka się możliwościom ich kategoryzacji sprzed kilku lat. Ma to szerokie konsekwencje również dla wyzwań, wobec których staje poradnictwo. Wydaje się, że współczesne poradnictwo wymyka się dotychczasowej hierarchizacji, dalekie jest od spójnego rozkładu funkcji, nie podobne do pomocy, której udzielano jeszcze kilkanaście lat temu (Piasecka, 2015, s.115). Zmienia się spectrum problemów, z którymi zmagają się współcześni, zmienia także spectrum oczekiwań osób potrzebujących pomocy i stosunek do poradnictwa. Stajemy się ludźmi bardziej otwartymi i skłonnymi do dialogu, ale jednocześnie mamy coraz mniej czasu, żyjemy niemal w stałym pośpiechu, w którym natychmiastowość i doraźność staje się normą działania.

Zaprezentowane $\mathrm{w}$ niniejszym artykule formy pomocy nie przez przypadek oscylują wokół poradnictwa opartego na dialogu. Poradnictwo wydaje się zmierzać ku działaniom mniej formalnym. Jest procesem, akcentującym niepowtarzalność człowieka, doceniającym jego rolę w budowaniu własnego życia, rozwiązywaniu problemów, tworzeniu spójnego obrazu samego siebie. Wydaje się, że współczesne poradnictwo wychodzi naprzeciw potrzebom dzisiejszych klientów, żyjących w świecie, który docenia samodzielność i afirmuje samorozwój.

Przedstawione formy pomocy, nie tylko stawiają jednostkę w centrum zainteresowania, ale także „stawiają na jednostkę”. W centralnym miejscu poradnictwa stoi osoba potrzebująca pomocy. Przed doradca znajduje się wyzwanie związane $\mathrm{z}$ odchodzeniem od arbitrażu i wydawania dyrektyw. Współczesny doradca nie planuje za pacjenta, nie komenderuje, nie sprawdza, staje się uważnym obserwatorem, partnerem do dialogu lub przewodnikiem.

Podsumowując, zauważyć trzeba, że w przedstawionych formach pomocy podkreśla się potencjał i zasoby osób zwracających się o nią, odchodzi od dyrektywnego kierowania ku kreowaniu sytuacji przez klienta. Promuje samodzielność jednostki, zachęca do autorefleksji, docenia branie od- 
powiedzialności za swoje życie a w konsekwencji zmierza ku podnoszeniu aktywności w stawianiu czoła trudnościom. Współczesne poradnictwo nie tylko docenia otwartość na zmiany, ale zachęca do wprowadzanie ich w życie, tworzenia kreatywnego spójnego obrazu samego siebie i poszukiwania rozwiązań. Stawia na dialog, partnerstwo, otwartość, nieszablonowość, „stawia na człowieka”. Dialog jest w relacji poradniczej nie tylko narzędziem, które prawidłowo użyte zapewnia sukces porady, ale również wyrazem personalistycznej relacji akcentującej indywidualność obu stron -pomostem między doradcą a klientem.

\section{Literatura:}

1. Bilska, E. (2012). Poszukiwanie pomocy-trudny proces decyzyjny. W: K. Marzec-Holka, T. Głowik, E. Bilska, H. Iwanicki (red.), Profilaktyka i resocjalizacja. Od dysfunkcji do funkcjonalności (s.182-192). Warszawa: Wydawnictwo Akademii Pedagogiki Specjalnej.

2. Cantelmi, T., Grifo, G. (2003). Wirtualny umysł. Fascynująca pajęczyna Internetu. Kraków: Wydawnictwo „Bratni Zew”.

3. Czerniawska, O. (1977). Poradnictwo, jako wzmacnianie środowiska wychowawczego. Warszawa: Instytut Wydawniczy CRZZ.

4. Ćwikła, L. (2012). Efektywność działań w procesie coachingowym. Między deklaracją a gotowością do zmiany W: M. Piorunek (red.), Dymensje poradnictwa i wsparcia społecznego w perspektywie interdyscyplinarnej (s. 49-68). Poznań: Wydawnictwo Naukowe UAM.

5. Drabik-Podgórna, W. (2015). Doradca coach czy „architekt życia”? O nowych obszarach i kompetencjach w obszarze profesjonalnej pomocy. W: M. Piorunek (red.), Dymensje poradnictwa i wsparcia społecznego $w$ perspektywie interdyscyplinarnej, (s.95-110). Poznań: Wydawnictwo UAM.

6. Gąsior, K. (2016). Terapia rodzin i poradnictwo rodzinne. W: K. Gąsior (red.), Budowanie mechanizmów prężności u wychowawców i wychowanków placówek opiekuńczo-wychowawczych typu rodzinnego (s. 1619). Kielce: Stowarzyszenie Pomocy Rodzinie PRO.

7. http://www. poradnictwo psychologiczne.pl

8. http://www.siteimpulse.com/blog/archiwum-historia-i-komercjalizacja-sieci/

9. Kozielska, J., Skowrońska-Pućka, A. (2015). Coaching - czym jest a czym nie jest? W: M. Piorunek (red.), Dymensje poradnictwa $i$ wsparcia społecznego w perspektywie interdyscyplinarnej, (s.37-48.). Poznań: Wydawnictwo Naukowe UAM.

10. Łobocki, M. (2007). W trosce o wychowanie w szkole. Kraków: Impuls.

11. Mugatroyd, S. (2000). Poradnictwo i pomoc. Poznań: Wydawnictwo: Zysk i S-ka.

12. Palmisano, B. (2017). PLISSIT Model: Introducing Sexual Health in Clinical Care, dokument dostępny w wersji cyfrowej pod adresem: https://www.psychiatryadvisor.com/practice-management/improving-provider-education-regarding-sexual-health/article/629446/

13. Piasecka, A. (2015). Poradnictwo wolontariackie w biegu życia- założenia formalno-merytoryczne. W: M. Piorunek (red.), Dymensje poradnictwa i wsparcia społecznego $w$ perspektywie interdyscyplinarnej (s.11-130). Poznań: Wydawnictwo Naukowe UAM.

14. Plichta P., Pyżalski J. (2013). Wychowanie i kształcenie w erze cyfrowej. Łódź: RCPS w Łodzi. Pobrane z: https://www.researchgate.net/profile/Piotr_Plichta/publication/259741014_Plichta_P_Pyzalski_ J_red_Wychowanie_i_ksztalcenie_w_erze_cyfrowej_RCPS_w_Lodzi_Lodz_2013_ss_268/links/02e7e52d83b6e373bf000000.pdf

15. Savickas, M.L. (2015). Life-Desing Counseling Manual, 2015, Pobrano z: http://www.vocopher.com/LifeDesign/LifeDesign.pdf

16. Savickas, M.L., Nota, L., Rossier, J., Dauwalder, J-P., Daurte, M. E., Guichard, J., Soresi, S., Van Esbroeck, R. (2009). Life designing: A paradigm for career construction in the $21^{\text {st }}$ century. Jornal of Vocational Behavior, 75(3), 8-12.

17. Skałbania, B, (2009). Poradnictwo pedagogiczne. Przegląd wybranych zagadnień. Kraków: Impuls.

18. Skowroński, D., Waszyńska, K. (2015). Poradnictwo on line, jako alternatywna forma pomocy psychopedagogicznej i terapeutycznej. W: M. Piorunek (red.), Dymensje poradnictwa i wsparcia społecznego w perspektywie interdyscyplinarnej (s. 81-94). Poznań: Wydawnictwo Naukowe UAM.

19. Smól, K. (2009). Poradnictwo telefoniczne na przykładzie fundacji Itaka. W: D. Zielińska-Pękał (red.), Refleksje o poradnictwie debiutujących doradców (s. 60-67). Zielona Góra: Wydawnictwo Uniwersytetu Zielonogórskiego. 